\title{
興味ある膝蓋骨腫腫瘍の一例
}

熊本大学医学部整形外科
$\begin{array}{cccccc}\text { 研 修 医 } & \text { 本 } & \text { 村 } & \text { 喜 } & \text { 代 } & \text { 二 } \\ \text { 教 } & \text { 授 } & \text { 北 } & \text { 川 } & \text { 敏 } & \text { 夫 } \\ \text { 講 } & \text { 師 } & \text { 高 } & \text { 木 } & \text { 克 } & \text { 公 }\end{array}$

\section{A Case Report of the Tumor of the Patella}

by

\author{
K. Motomura, T. Kitagawa and K. Takagi \\ Department of Orthopedic Surgery, Kumamoto University \\ Medical School, Kumamoto
}

Benign chondroblastoma was separated from the category of Giant Cell Tumor by H. L. Jaffe and L. Lichtenstein in 1942. Since then, we can find many reports about Benign Chondroblastoma in the domestic and the foreign.

This time we could have a chance to treat this tumor which was arising from the patella.

Judging from many reports, it was very rare to find Benign Chondroblastoma in the patella.

We laid importance on histological findings of this case to diagnose this tumor as Cystic Benign Chondroblastoma. Still more, we tried to compare statistically Japanese cases with foreign cases.

\section{概 要}

最近私達は, 発生部位上極めて稀な㮏蓋骨腫瘍の一 例を経験し，良性軟骨芽細胞腫という組織学的・文献 的確信を得たので，乙とに報告し，若干の文献的考察 を行いたい.

$$
\text { 症例 }
$$

患者は 19 才の男性で大学生である. 17 才の高校生 当時, かなり活発なクラブ活動をしていたが，その頃 より右膝部の異和感之歩行時の疼痛に気付き, 近医で 湿布等の加療を受け一時, 愁訴は消失していた. 大学 入学後, 再び同部の疼痛が出現し, 更に軽度の腫脹が 現れた為, 某国立病院を受診し, 右膝蓋骨の腫瘍を疑 われ当科へ紹介され入院する.

\section{入院 時 所見}

患者は自力歩行で入院し歩容は右足をかばうように右 膝を軽度屈曲して歩く. 外観は, 右膝部の軽度腫脹を
認めるが, 同部の熱感, 発赤, 膝蓋骨躍動はない, 右 膝の可動域も正常であるが，屈曲時に疼痛を訴える. 大腿周径, 下腿周径も健側之差はない，血液生化学所 見あ全く正常範囲内であった.

\section{$\mathbf{X}$ 線 所 見}

図 1-a の如く単純 $\mathrm{X}$ 線で, 右膝蓋骨に明らかな透 亮像を認め，周囲の骨硬化像むみられた。しかし透亮 像内の石灰化等の所見はみられなかった．また右大腿 動脈より血管造影を行ったが図 1 - b の如く右腅蓋骨 およびその周囲への新生血管, 血管集皘像, 腫掦陰影 等の異常所見はなかった.

\section{手術及び手術所見}

手術は硬膜外麻醉下に行い，皮切を膝蓋骨下縁に沿 うU字型にいれ，膝蓋靱帯を中央で 2 分して，骨より 十分に剝離後, 全剔し同部に広筋膜を㨂入補強して術 創を閉じた. 摘出した膝蓋骨は概ね外観は正常であっ たが全般的に肥厚を認めた 


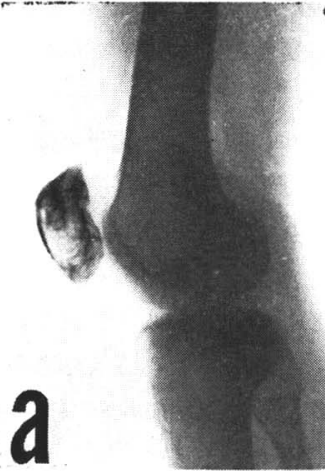

a. 右膝蓋骨単純 X 線

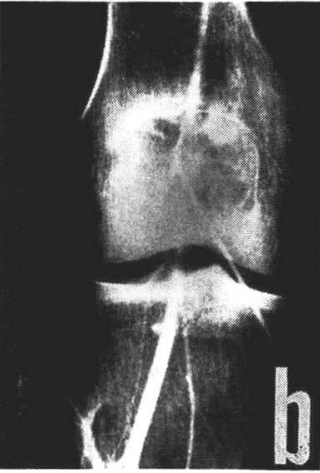

b. 右大腿動脈造影

図 1

膝蓋骨に割をいれると内部に空洞が形成され内壁に は赤褐色の線維性付着物を認め, 内部に $3 \mathrm{ml}$ の黄褐 色液をいれていた．この液のアルカリフォスファター ゼ值は $567 \mathrm{mU} / \mathrm{ml}$ 以上と極めて高值であった.

術後経過は術後 1 週で膝の届曲訓練を開始し筋力増 強，体重負荷，関節可動域の拡大訓練を行い 7 週目で 退院した. 術後 1 年たった今日でも右膝の愁訴はな W.

\section{病 理 所見}

H.E. 染色で図 2-1 の如く軟骨芽細胞，少数の巨 細胞を認め, 更にアルシャンブルー染色で軟骨基質の 形成を認めた. 図 $2-2$ の如く渡銀染色により好銀線 維が軟骨芽細胞をとりまいている所見が得られた。

以上の 知見から私達は本例を良性軟骨芽細胞腫之 診断し，特にのう腫の形成を認めた事から Schajowicz $z^{7)}$ の命名にならい，のう腫性良性軟骨芽細胞腫 (Cystic Benign Chondroblastoma) と診断した.

\section{文献的考察}

良性軟骨芽細胞腫は，以前は巨細胞腫の亜型と考え られていたが, 1942 年 Jaffe と Lichtenstein ${ }^{4}$ が この腫瘍を巨細胞腫とは別個の腫瘍として記載してか ら多くの学者の同意するところとなった. 彼らの記載 によると本腫瘍は, 発育のまだ終っていないエピフィ 一ゼに好発し従ってその発生年令も，思春期ないしは 20 才までに集中すると述べている，本邦での良性軟 骨芽細胞腫の報告数をみてみると 1974 年全日本骨腫 瘍統計によれば，昭和 39 年から 49 年までに 64 例が

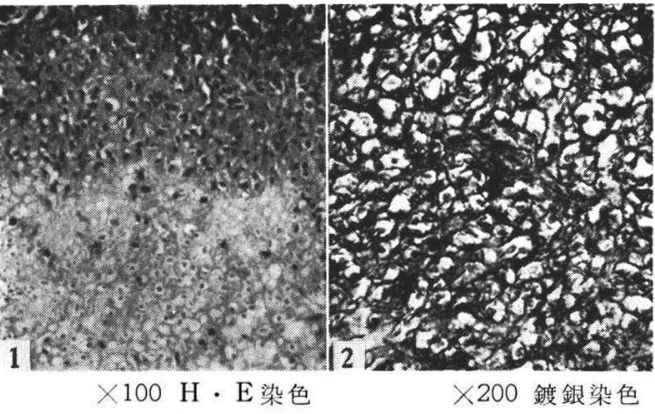

軟骨芽細胞，軟骨基質 軟骨芽細胞周囲に好銀 巨細胞を認む

線維の存在がわかる

図 2

報告されているにすぎない，外国では，数多い報告が みられ Jaffe ${ }^{5)}$ が 458 例, Salzer が 182 例を報告し ている.

本腫瘍の発生率は本邦では昭和 39 年から 49 年まで の全骨腫痬の $0.3 \%$, Huvos は $1 \%, \mathrm{Kunkel}^{7)}$ は 1 \%以下であったと報告している.

性別では, 本邦では 3:1 で男性に多く, Jaffe は $2: 1$, Schajowicz は3:1, Huvos は $2: 1$, Dahlin は 3:1 でいずれも男性に多い事を指摘している. 年令別では, Jaffe の症例の平均年令は 55.5 才, $\operatorname{Codman}^{7)}$ は 17.0 才, Smith ${ }^{\text {2) }}$ は 103 例のうち 21 才 以上はわずかに 7 例と述べ, Dahlin ${ }^{2)}$ の例では $64 \%$ が 10 才代である. 本邦では $58 \%$ が 20 才までにおて り, 24 才までに 85 \%が発生し, 同様の傾向がうかが われる.

好発部位は表 1 - $\mathrm{a}$ に本邦例を記しているが，男性 では，脛骨，上腕骨，大腿骨に，女性ではその $2 / 3$ が 大腿骨に発生し, 表 1 - b の如く, 外国統計と比較し て大腿骨，上腕骨，脛骨の三大好発部位は同じ傾向に ある。

良性軟骨芽細胞腫の膝蓋骨への発生例は, 外国では 1963 年 J. Cohen ${ }^{1)}$ が最初の記載をして以来 15 例が みられ，本邦では 1970 年，本邦初例とされる未沢 ${ }^{9)}$ の報告がみられ，その後塚本 ${ }^{11}$ の報告が散見される 程度である。

膝盖骨そのものに発生する腫瘍も表 1 -C の如く昭 和 39 年から 49 年までに 37 例の報告しかなく，乙の ような事実から本例のように膝蓋骨に発生した良性軟 骨芽細胞腫は，極めて珍らしいと考えられる.

本例の如く明らかなのう腫を形後する例は, Scha- 
表 $1 \mathbf{a}$ 本邦に打ける良性軟骨芽細胞腫に 関する統計性別，部位別，年令別 発生頻度（昭和39～49）

A. 性別; 総数 64

$\begin{array}{lll}\text { 옹 } & 49 & 76.6 \% \\ \text { 우 } & 15 & 23.4 \%\end{array}$

B. 部位別; 総数 64

\begin{tabular}{|c|c|c|c|}
\hline & $\hat{o}($ & 総 49） & 우 (総 15) \\
\hline $\begin{array}{l}\text { 大腿骨 } \\
\text { 上腕骨 } \\
\text { 脛骨 } \\
\text { 䐂蓋骨 }\end{array}$ & $\begin{array}{c}9 \text { 例 } \\
11 " \prime \\
14 \prime \prime \\
1 " \prime\end{array}$ & $\begin{array}{r}18.4 \% \\
22.4 \% \\
28.6 \% \\
2.0 \%\end{array}$ & $\begin{array}{cc}10 \text { 例 } & 66.7 \% \\
2 " & 13.3 \% \\
2 " & 13.3 \% \\
0 " & 0 \%\end{array}$ \\
\hline
\end{tabular}

C. 年令別発生（男女計 64）

$\begin{array}{lll}10 \sim 14 \text { 才 } & 18 \text { 例 } & 28.1 \% \\ 15 \sim 29 & 19 \prime \prime & 29.7 \% \\ 20 \sim 24 & 11 & 17.2 \%\end{array}$

表 $1 \mathbf{b}$ 外国での良性軟骨芽細胞腫の登録 者, 例数, 発生部位

\begin{tabular}{|c|c|c|c|}
\hline M. Salzer & (1968) & 182 例 & \\
\hline F. Schajowicz & (1976) & 69 " & \\
\hline D. C. Dahlin & (1972) & $125 "$ & \\
\hline A. G. Huvos & (1973) & $458 \prime \prime$ & 計 834 例 \\
\hline $\begin{array}{l}\text { 大腿骨 } \\
\text { 上腕骨 } \\
\text { 脛 骨 } \\
\text { 膓 骨 } \\
\text { 县甲骨 } \\
\text { 㮏蓋骨 }\end{array}$ & $\begin{array}{l}267 \text { 例 } \\
182 \prime \prime \\
136 " \prime \\
44 \prime \prime \\
29 \prime \prime \\
15 \prime \prime\end{array}$ & & $\begin{array}{r}32.0 \% \\
21.8 \% \\
16.3 \% \\
5.3 \% \\
3.5 \% \\
1.8 \%\end{array}$ \\
\hline
\end{tabular}

表 1 c 昭和39〜49年の膝蓋骨腫場, 全日本骨腫湟統計（1974）

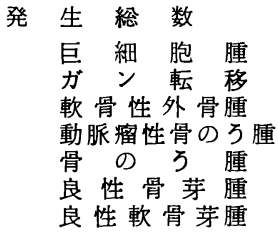

12
5
4
4
2
1
1

jowicz ${ }^{7)}$ の報告によると全軟骨芽細胞腫の $17 \%$ ほ られるという事である. 本例の如く空洞内より得られ た液のアルカリフォスファターゼ值が高值を示すかに ついては，文献的に確認する事ができなかった.

レントゲン所見は，本例の如くほとんどが境界鮮明 な透亮像を示し，斑点状の石灰化や空洞周囲の骨硬化 像をみることあ多い.

良性軟骨芽細胞腫の組織学的特徵は, Jaffe, Lichtenstein の記載によるところが大きいが，彼らは軟
骨芽細胞と巨細胞の存在を重視し，この巨細胞は巨細 胞腫のそれと違って，二次的変性による単核細胞の融 合によって発生すると考えた。

この巨細胞は光顕的に大きな血管や出血巣の周囲に みられることが多い. 従ってその性格は巨細胞腫のも のよりあおとなしいと考えられている．しかしVallo6) （1951）のように，巨細胞の起源を腫瘍細胞そのもの の合胞体であると考えるものああり，どちらが真なの かは不明である.Jaffe らは，本腫瘍にみられる軟骨 様組織は成熟する事なく壊死に陥り，同部は膠原化， 石灰化したり硝子様組織に変化すると述へ，特に細胞 壊死亡細胞内外での石灰化を本腫瘍の特徴の 1 つにか かげている.

しかし 1970 年の未沢の報告では，本邦例では典型 的石灰化を呈する症例は少いということである.

一方 Schajowicz や Callard ${ }^{7)}$ らは, 組織学上の 特徵として軟骨芽細胞, 軟骨様組織, 変性軟骨細胞, 壊死巣，線維化組織をあげ，石灰化についてはあまり 強調せず，むしろ Gitter 染色における，軟骨芽細胞 をよりまいて存在する 好銀線維の存在を強調してい る. 更に, 腫瘍組織内には血管の豊富な増殖があり, ここよりの出血巣などがのう腫性変化をきたすと述 べ, 動脈瘤性骨のう腫との鑑別が困難であると指摘し ている.

組織化学的にはグリコーゲン²) の含量の多いという 事が多くの方面から指摘されている.

本腫瘍細胞の 起源に関してはまだ一定しておらず Jaffe の様に Cartilago germ cell と考える者や, Lichtenstein の様に性ホルモンに反応する Epiphyseal cartilago center よりの発生を主張する者, Schajowicz の如く Reticulo-Histio cytic origin と考える者など万人の賛同するまでには至っていない が 1964 年 R.A. Welch ${ }^{2)}$ は, その光顕的, 電顕的 所見，および培養細胞の所見から chondroblast は 人間の正常な成人の Epiphyseal cartilago に類似 していると報告している.

本腫瘍の予後は極めて良いが，放射線治療後の数例 に悪性化 2)したという報告がある.

鑑別診断上重要な疾患は, 巨細胞腫，骨のう腫，動 脈瘤性骨のう腫, 軟骨粘液様線維腫, 軟骨腫, 骨肉 腫, 軟骨肉腫が挙げられる. 
結語

発生部位上極めて稀と考えられる膝蓋骨の良性軟骨 芽細胞腫の治験例を報告し， あわせて文献的考察を行 い本邦と国外での良性軟骨芽細胞腫の諸点を比較検討 した.

御助力をいただいた本田五男技官に心から感謝の意 を表します。

\section{参考文 献}

1) Cohen J.: Benign chondroblastoma of the Patella. J. Bone Joint Surg., 45-A; 824-826, 1963.

2) Dahlin D. C.: Benign chondroblastoma, A study of 125 cases. Cancer, 30; 401-413, 1972.

3) Gravanis M. B.: Benign chondroblastoma. Amer. J. Clini. Path., 55; 624-631,
1971.

4) Huvos A. G.: Chondroblastoma of Bone. Clini. Orthop., 95; 300-312, 1973.

5) Jaffe H. L., Lichtenstein L. : Benign chondroblastoma of bone. Amer. J. Path., 18; 969-983, 1942.

6) Levin G. D. : Chondroblastoma. -The nature of the Basic cell. Cancer, 29; 15461562, 1972.

7) Schajowicz: Epiphysial chondroblastoma of the bone. J. Bone Joint Surg., 52-B; 205-226, 1970.

8) Smith D. A.: Benign chondroblastoma. J. Bone Joint Surg., 44-A ; 571-577, 1962.

9）米沢：滕蓋骨に発生した良性軟骨芽細胞腫，整 形外科. 21: 46-51, 1970.

10）塚本憲甫：骨軟部腫堭図譜. 中山書店, 東京, 1972.

11) Welsh R. A.: A histogenetic study of chondroblastoma. Cancer, 17 ; 578-589, 1964. 